\title{
PERAN KEPEMIMPINAN KEPALA SEKOLAH DALAM MENINGKATKAN KINERJA GURU
}

\author{
The Role of Principal Leadership in Improving Teacher Performance
}

\author{
Sonedi ${ }^{1 *}$ \\ Tutut Sholihah ${ }^{2}$ \\ Dihasbi $^{3}$ \\ IUniversitas Muhammadiyah \\ Palangkaraya, Palangka Raya, \\ Central Kalimantan, Indonesia \\ 2Institut Agama Islam Negeri \\ Palangkaraya, Palangka Raya, \\ Central Kalimantan, Indonesia \\ 3Praktisi Pendidikan Palangka \\ Raya, Palangka Raya, Central \\ Kalimantan, Indonesia \\ *email: sonedi.lilik@gmail.com
}

Kata Kunci:

Kepala Sekolah

Kepemimpinan

Kinerja Guru

Keywords:

Headmaster

Leadership

Teacher Performance

\begin{abstract}
Abstrak
Penelitian ini bertujuan untuk mengetahui kepemimpinan kepala madrasah di MTsN I Model Palangkaraya dalam meningkatkan kinerja guru MTsN I Model Palangkaraya. Pendekatan yang digunakan dalam penelitian ini adalah pendekatan kualitatif dengan metode studi kasus. Pengumpulan data menggunakan teknik observasi, wawancara dan studi dokumentasi dengan menitik beratkan sumber data informan yaitu: Kepala madrasah, guru, dan peserta didik untuk mengokohkan keabsahan data yang diperoleh. Berdasarkan hasil penelitian bahwa Kepala madrasah di MTsN I Model Palangka Raya memiliki tipe kepemimpinan demokratis dan sangat berperan dalam menjalankan kepemimpinannya sebagai edukator, manager, administrator, supervisor, leader, dan motivator dalam meningkatkkan kinerja dalam perencanaan, pelaksanaan dan evaluasi pembelajaran di kelas, dan selalu memberdayakan sumberdaya manusia dalam pengambilan keputusan. Kinerja guru di MTsN I Model ini, sudah melakukan analisis minggu efektif, prota, prosem, tersedianya silabus media, daftar nilai, dan daftar hadir peserta didik. Kinerja guru mata pelajaran dalam perencanaan pembelajaran sudah dalam kategori baik sekali. Guru sudah disiplin dalam menjalankan tugasnya sebagai Pendidik. Dalam pelaksanaannya untuk meningkatkan kinerja guru, kepala madrasah sudah mengikutkan para guru setiap ada pelatihan-pelatihan sesuai dengan bidang studi. Disamping itu kepala madrasah juga memberikan penghargaan kepada guru, walaupun tidak berupa materi akan tetapi berupa dukungan mental dan pujian untuk terus mengembangkan potensi yang dimilikinya.
\end{abstract}

\begin{abstract}
This study aims to determine the leadership of the head of the madrasah at Palangkaraya MTsN I in improving the performance of the Palangkaraya I MTsN Model teacher. The approach used in this study is a qualitative approach with a case study method. Data collection uses observation, interview and documentation study techniques with emphasis on informant data sources, namely: Head of madrasas, teachers, and students to strengthen the validity of the data obtained. Based on the results of the study that the head of the madrasa in Palangka Raya I MTsN Model has a type of democratic leadership and is very instrumental in carrying out its leadership as educator, manager, administrator, supervisor, leader, and motivator in improving performance in planning, implementing and evaluating classroom learning, and always empower human resources in decision making. Teacher performance in $M T s N$ I This model, has carried out an effective week analysis, prota, prosem, availability of media syllabus, list of values, and attendance list of students. The performance of subject teachers in learning planning is in a very good category. The teacher has been disciplined in carrying out his duties as an Educator. In its implementation to improve teacher performance, the headmaster of the madrasah has included the teachers every time there are trainings in accordance with the field of study. Besides that the headmaster also gives awards to the teacher, although not in the form of material but in the form of mental support and praise for continuing to develop the potential he has.
\end{abstract}

Accepted

October 2018

Published

December 2018 membentuk baik atau tidaknya pribadi manusia dalam kehidupan ini menurut ukuran normatif. Pada sisi lain, pendidikan merupakan proses pemanusiaan menuju lahirnya insan bernilai secara kemanusiaan (Danim, 2006). Ki Hajar Dewantara mengemukakan, pendidikan merupakan faktor terpenting untuk membentuk
Pendidikan merupakan faktor utama dalam pembentukan pribadi manusia. Bahkan pendidikan sudah mewarnai perjalanan hidup manusia sejak manusia itu dilahirkan sampai dapat berinteraksi dengan lingkungan sekitarnya. Pendidikan sangat berperan dalam 
manusia berbudi luhur, berkepribadian, dan bersusila (Wibowo, 20I2). Di Indonesia memiliki dua karakteristik model pengelolaan pendidikan formal yaitu pendidikan formal yang dikelola oleh Kementerian Pendidikan dan Kebudayaan dan Kementrian Agama, dalam penelitian ini peneliti memfokuskan pada Madrasah Tsanawiyah.

Untuk menyiapkan generasi emas bangsa Indonesia, lembaga madrasah dalam setiap jenjangnya di Indonesia pada umumnya, dan di Kalimantan Tengah pada khususnya mesti terus berbenah, berupaya melakukan inovasi agar dapat beradaptasi dengan perubahan serta perkembangan jaman modern ini dalam konsep penguasaan ilmu pengetahuan dan teknologi sesuai jenjang pendidikan di madrasah. Ilmu pengetahuan dan teknologi tersebut diharapkan dapat diaplikasikan dalam perilaku sehari-hari untuk meningkatkan tarap hidup dalam berbagai aspek (Ngafifi, 20I2). Lembaga madrasah harus dengan kesungguhannya melaksanakan tugas serta fungsinya dengan berupaya mewujudkan tujuan Pendidikan nasional yang diamanatkan dalam UndangUndang Sistem Pendidikan Nasional No. 20 Tahun 2003:

"Pendidikan Nasional berfungsi mengembangkan kemampuan dan membentuk watak serta peradaban bangsa yang bermartabat dalam rangka mencerdaskan kehidupan bangsa, bertujuan untuk berkembangnya potensi peserta didik agar menjadi manusia yang beriman dan bertakwa kepada Tuhan Yang Maha Esa, berakhlak mulia, sehat, berilmu, cakap, kreatif, mandiri dan menjadi warga Negara yang demokratis serta bertanggung jawab."

Berdasarkan tujuan pendidikan nasional tersebut jelas bahwa yang dikehendaki pemerintah dalam bidang pendidikan adalah meningkatkan sumber daya manusia yang berkualitas baik secara kognitif, afektif dan psikomotoriknya. Untuk menciptakan sumber daya yang berkualitas tersebut diperlukan adanya pendidikan yang berkualitas pula, tanpa pendidikan yang berkualitas tidak menutup kemungkinan tujuan pendidikan nasional akan terhambat. Untuk mewujudkan pendidikan yang berkualitas sebagaimana yang dikemukakan di atas, dibutuhkan seorang pemimpin yang selalu menyadari bahwa anggota organisasinya merupakan sumberdaya manusia yang sangat berharga karena dikaruniai otak dan akal pikiran, seorang pemimpin hendaknya selalu berupaya menggali, memanfaatkan dan meningkatkan kreatifitas anggotanya untuk mencapai prestasi yang tinggi (Nawawi \& Hadari, 2004).

Mutu pendidikan akan tercapai apabila komponen yang terdapat dalam meningkatkan mutu pendidikan memenuhi syarat tertentu. Komponen yang berperan dalam peningkatan mutu pendidikan salah satunya adalah tenaga pendidik yang bermutu, yaitu yang mampu menjawab tantangan-tantangan dengan cepat dan bertanggung jawab. Tenaga pendidik mempunyai peran yang sangat strategis dalam pembentukan pengetahuan, keterampilan, dan karakter peserta didik, karena itu tenaga pendidik yang profesional akan melaksanakan tugasnya secara profesional sehingga menghasilkan peserta didik yang lebih bermutu. Untuk meningkatkan kualitas dan kinerja mengajar guru, banyak faktor yang mempengaruhinya, di antaranya adalah kepemimpinan kepala madrasah, karena kepala madrasah harus memiliki signifikansi yang kuat dan terfokus jika kepemimpinan itu memahami tujuan pendidikan secara utuh dan menyeluruh. Keberhasilan memimpin di satuan pendidikan, tentu saja tidak terlepas bagaimana seorang pemimpin satuan pendidikan memahami apa yang menjadi dasar utama baginya untuk membawa satuan pendidikan ke arah yang sudah ditetapkan. Salah satu upaya kepala madrasah dalam memajukan madrasah agar berkinerja baik yaitu dengan melakukan pembinaan kepada guru. Pembinaan tersebut dilakukan agar guru melaksanakan tugas dengan jujur, bertanggung jawab, efektif dan efisien (Sagala, 2018).

Belakangan ini makin banyak literatur reformasi pendidikan yang secara konsisten menekankan bahwa 
pemimpin yang efektif tidak menerapkan secara langsung, tetapi sangat berpengaruh pada kemampuan madrasah untuk meningkatkan mutu implementasi program-program dan keberhasilan akademik peserta didik. Sementara aktivitas belajar peserta didik di madrasah semakin diterima sebagai menempati posisi “pertama, terakhir, dan selalu” tergantung pada kualitas guru. Ini menunjukkan pentingnya kualitas kepemimpinan dalam menentukan kinerja guru dan mutu pengajaran di kelas (Danim, 20l0).

Berdasarkan hasil observasi awal yang dilakukan peneliti menemukan bahwa kondisi sumber daya madrasah yang heterogen, terdiri dari perbedaan suku, bahasa, warna kulit, jenis kelamin, perbedaan usia, dan latar belakang pendidikan yang berbeda merupakan sebuah tantangan dalam memimpin. Kondisi tersebut sudah menjadi hukum alam di manapun kepemimpinan itu berada. Kepala madrasah/madrasah sebagai tokoh sentral yang bertanggung jawab terhadap kemajuan pendidikan di madrasah, peneliti melihat kepala madrasah di MTsN I Model Palangka Raya datang lebih awal di madrasah untuk melakukan pengontrolan kesiapan kondisi madrasah sebelum pembelajaran dan aktivitas lainnya di mulai. Pada waktu luang, kepala madrasah lebih jarang berada di ruang kerjanya. Untuk upaya meningkatkan kemajuan madrasah, beliau selalu menempatkan diri sebagai bagian dari kelompok warga madrasah dengan memusatkan perhatiannya untuk berkumpul, bercanda, bercerita dan berdiskusi secara kelompok ataupun individual.

MTsN I Model Palangka Raya merupakan madrasah yang berprestasi di Kalimantan Tengah, baik di bidang akademik maupun non akademik. Prestasi tersebut di raih dari berbagai event, baik di tingkat kota Palangka Raya, bahkan di tingkat nasional. Keunggulan prestasi yang dimiliki MTsN I Model Palangka Raya sebagai kontribusi dari peran kepemimpinan kepala madrasah. Berkaitan dengan keunggulan madrasah di bidang akademik, kepala madrasah di MTsN I Model Palangka
Raya menjalankan peran kepemimpinannya dalam meningkatkan kinerja guru dalam pembelajaran di kelas yang meliputi kinerja guru di bidang perencanaan, pelaksanaan dan evaluasi pembelajaran.

Kepala madrasah MTsN I Model Palangka Raya, memberikan dorongan, arahan, pembinaan, keteladanan, dan pengawasan kepada guru dalam meningkatkan kinerjanya agar guru di madrasah memiliki perangkat pembelajaran yang lengkap sehingga pembelajaran di kelas dapat berjalan sesuai prosedur pelaksanaannya. Disamping itu untuk meningkatkan kemampuan profeisonal guru dalam menjalankan tugasnya kepala madrasah di MTsN I Model Palangka Raya, mengikutsertakan guru dalam kegiatan workshop, seminar, dan musyawarah guru mata pelajaran (MGMP) sesuai dengan kompetensi keilmuan guru yang berkontribusi terhadap peningkatan kinerjanya dalam memberikan pendidikan dan pembelajaran di kelas.

Berdasarkan hal tersebut ada banyak capaian yang telah dilakukan kepala madrasah antara lain tingkat kelulusan pada MTsN I Model tersebut dalam kurun waktu tiga tahun terturut-turut meluluskan peserta didiknya 100\%. Kondisi tersebut menandakan bahwa proses pembelajaran di MTsN I Model Palangka Raya dapat berjalan dengan efektif dan efisien dalam aspek perencanaan, pelaksanaan dan evaluasi pembelajaran di kelas, hal tersebut karena adanya peran kepemimpinan kepala madrasah dalam meningkatkan kinerja guru di MTsN I Model Palangka Raya. Konsep dari kepemimpinan sangat beragam, sehingga untuk mendefinisikan istilah kepemimpinan (leadership) secara tepat bukanlah hal yang mudah sampai-sampai Grenberg dan Baron memandang kepemimpinan serupa dengan cinta, dalam artian banyak orang yang meyakini bahwa ia bisa memahami tentang kepemimpinan tetapi menemukan kesulitan ketika mendefinisikannya. Davis \& Thomas (1989) memberikan saran kepala madrasah hendaknya peduli dan berurusan dengan nilai-nilai dan harapan-harapan yang selalu bersaing dan disertai 
dengan keterbatasan sekolah dalam ruang, staf, dana, perlengkapan, dan bahan.

Proses pendidikan di suatu sekolah/madrasah banyak ditentukan oleh gaya kepemimpinan kepala madrasah, sebab kepala sekolah/madrasah adalah orang yang paling bertanggung jawab atas segala sesuatunya yang sudah, sedang dan yang akan terjadi di sekolah tersebut. Gaya kepemimpinan adalah sekumpulan ciri yang digunakan pimpinan untuk mempengaruhi bawahan agar sasaran organisasi tercapai atau dapat pula dikatakan bahwa gaya kepemimpinan adalah pola perilaku dan strategi yang disukai dan sering diterapkan oleh serang pemimpin (Rivai \& Mulyadi, 2017). Kepala sekolah/madrasah sebagai manajer pendidikan adalah merupakan aplikasi dari fungsi manajemen yang ditangan pemimpin organisasi. Kutipan ini menjelaskan bahwa tugas kepala sekolah sebagai seorang manajer dan administrator pendidikan itu sebenarnya mencakup fungsi-fungsi pokok manajemen, yang terdiri atas perencanaan, pengorganisasian, pelaksanaan, pengkoordinasian, dan pengendalian (Suyanto, 2014).

Berdasarkan landasan teori di atas, maka dapat dikatakan bahwa kemampuan seseorang dalam memimpin sebuah organisasi persekolahan adalah merupakan bagian dari kompetensi manajerial dimana kepala sekolah/madrasah dalam menjalankan tugasnya mempengaruhi dan membimbing guru-guru melakukan kegiatan mendidik dan mengajar serta kegiatan lainnya di madrasah yang bertujuan meningkatkan mutu pendidikan. Karena kepemimpinan bagian dari kompetensi manajerial pekerjaannya lebih terfokus pada perhatian kepala sekolah terhadap proses pembelajaran, dan hasil belajar yang dicapai peserta didik, hal ini sekaligus merefleksikan keberhasilan kerja kepala sekolah/madrasah dan guru-guru.

Konsep kepemimpinan pengajaran juga bagian dari aplikasi kompetensi manajerial dalam melaksanakan tugas seorang kepala sekolah/madrasah. De Bevoise menjelaskan "Instructional leadership means those action that a principal takes, or delegates to other, to promote grout in student learning". Selanjutnya menurut Greenfield (Davis \& Thomas, 1989) menyatakan "Instructional leadership as action undertaken wits the intention of developing a productive and satisfying working environment for teacher and desirable learning conditions and outcomes for children, adding that suet leadership is effective to the extent these broad purposes are achieved". Dari uraiaan di atas, tampak jelas bahwa kepemimpinan pendidikan itu berlangsung dan terjadi melalui aktivitasaktivitas, baik yang dilakukan oleh kepala madrasah maupun oleh para guru dan staf administrasi. Menurut Sergiovanni (20I4), “Curriculum and program development, supervision and evaluation, and student discipline are examples of task areas that might come to mind". Kurikulum dan pengembangan program, pengawasan dan evaluasi, dan disiplin peserta didik adalah contoh dari wilayah tugas yang dilakukan dari pemikiran kepala sekolah. Memperhatikan berbagai kegiatan kepala sekolah/madrasah menurut pendapat tersebut, terlihat bahwa tugas kepala sekolah/madrasah sebagai manajer pendidikan. Berdasarkan kenyataan tersebut, maka dapat diketahui bahwa perbedaan antara tugas-tugas manajerial dan kepemimpinan kepala sekolah merupakan bagian dari kompetensi manajerial. Pendapat lain dari Davis \& Thomas (1989), "effective principals have a strong vision of what their schools can be, and they encourage all staff to work towerd realizing that vision". Dengan demikian sebuah visi memiliki gambaran yang jelas, menawarkan suatu cara yang inovatif untuk memperbaiki, mendorong adanya tindakan-tindakan yang mungkin dilakukan untuk mewujudkan perubahan yang lebih baik. Hasil penelitian dari Simanjuntak (2000) menyatakan bahwa pemimpin sangat berperan dalam menciptakan komitmen dan tujuan pendidikan. Fullan (2007) mengemukakan bahwa kepala sekolah terbukti mempengaruhi implementasi, pemeliharaan, perubahan, dan berkorelasi dengan mutu lulusan peserta didik. 
Demikian juga yang dikemukakan oleh Dunkin (200I) dalam penelitiannya mengungkapkan bahwa variabel pokok yang mempengaruhi hasil belajar atau mutu lulusan yaitu kompetensi kepemimpinan kepala sekolah dalam proses belajar mengajar, potensi pendidik dan potensi peserta didik. Suryadi \& Tilaar (1993) menyatakan bahwa kompetensi pemimpin madrasah atau lembaga pendidikan merupakan faktor utama untuk menentukan mutu lulusan yang baik.

Hasil penelitian Moedjiarto (2002) menyebutkan kepemimpinan kepala sekolah pada SMA Swasta di Surabaya yang tergolong unggul ternyata dinilai cukup baik dalam arti kepala sekolah mempunyai pemahaman yang baik terhadap visi dan misi sekolahnya, melaksanakan kontrol terhadap peserta didik dan proses pembelajaran terutama tugas para gurunya. Lebih lanjut Moedjiarto menyatakan keefektifan guru merupakan salah satu karakteristik yang berpengaruh pada prestasi belajar peserta didik di sekolah.

Temuan Hackman \& Oldman yang dirujuk Sergiovanni (20I4) menyatakan bahwa guru-guru yang diberi petunjuk tentang teknik pelaksanaan pekerjaan secara jelas dan wajar akan terdorong untuk meningkatkan kualitas dan kemampuan kerjanya. Dengan demikian, keberhasilan sekolah dalam mencapai tujuan pendidikan tidak saja dipengaruhi oleh kinerja guru, namun ikut berperan pula faktor kompetensi kepala sekolah dalam manajemen serta dalam menciptakan suasana pembelajaran yang kondusif. Blumberg \& Greenfield ( 1986 ) dalam penelitiannya mengungkapkan bahwa salah satu karakteristik kepala sekolah yang efektif adalah kepala sekolah yang mempunyai harapan tinggi terhadap prestasi peserta didik dan unjuk kerja guru. Agar dapat merealisasikan harapan tersebut kepala sekolah harus mampu mengoptomalkan sumberdaya di sekolah dengan menjalankan kompetensi manajerial. Keterampilan manajerial kepala sekolah memberikan konstribusi yang signifikan terhadap kinerja guru dalam mengajar SMU baik Negeri dan Swasta. Lebih lanjut jika kepala sekolah mengaktualisasikan keterampilan manajerialnya secara nyata dan objektif dalam mengembangkan seluruh aktivitas di sekolah yang dipimpinnya, maka aktivitas guru berlangsung baik dan berdampak positif terhadap hasil kerja guru di sekolah (Suwarni, 2009).

\section{METODOLOGI}

Pengamatan mendalam dalam latar penelitian dan situasi yang wajar, yang dikenal sebagai pendekatan kualitatif atau naturalistik, dimana situasi akan tetap bersifat natural, alamiah, wajar dan tidak ada tindakan manipulasi, pengaturan ataupun eksperimen (Bogdan \& Biklen, 2007). Penelitian ini menggunakan rancangan studi kasus, hal ini sesuai dengan pernyataan Yin (2002) memberikan batasan yang lebih bersifat teknis dengan penekanan pada ciri-cirinya yaitu studi kasus adalah suatu inkuiri empiris yang menyelidiki fenomena di dalam konteks kehidupan nyata, bilamana: batasanbatasan antara fenomena dan konteks tidak tampak dengan tegas, dan di mana: multisumber bukti dimanfaatkan.

Penelitian ini menggunakan pendekatan kualitatif yang menjadi alat utama adalah manusia (human tool) artinya peneliti sendiri sebagai instrumen (key instrument) (Bogdan \& Biklen, 2007). Kehadiran peneliti di lokasi penelitian untuk meningkatkan intensitas peneliti berinteraksi dengan sumber data guna mendapatkan informasi yang lebih valid dan abash tentang fokus penelitian. Penelitian dilaksanakan di Madrasah Tsanawiyah Negeri I Palangka Raya. Alasan dipilihnya Madrasah Tsanawiyah Negeri I Palangka Raya sebagai tempat penelitian didasarkan pada keunikan, menarik dan merupakan salah satu madrasah negeri terbaik yang menjadi pilihan utama orang tua untuk menyekolahkan anaknya setelah menamatkan madrasah dasar sederajat, yang ada di Kota Palangka Raya yang menjadi tanggungjawab pengawasannya di bawah Kementrian Agama Kota Palangkaraya. 
Teknik pengambilan sampel dalam penelitian ini adalah purposive sampling atau sampel bertujuan yaitu kepala madrasah, wakil kepala madrasah, guru dan peserta didik. Teknik pengumpulan data yang sesuai dan relevan dengan fokus dan tujuan penelitian, maka dilakukakan dengan menggunakan tiga teknik yaitu wawancara mendalam (in-depth interviewing), observasi partisipasi (participant observation), dan Studi Dokumen (Bogdan \& Biklen, 2007). Teknik analisis data dalam penelitian ini menggunakan analisis deskriptif berdasarkan hasil penelitian dengan prosedur analisis data yang digunakan dalam penelitian ini adalah reduksi data, data yang terdapat dalam penelitian ini akan direduksi, agar tidak bertumpuk-tumpuk guna untuk memudahkan pengelompokan data serta memudahkan dalam menyimpulkannya, penyajian data, adalah sekumpulan informasi tersusun dari kemungkinan adanya penarikan kesimpulan dan pengambilan tindakan, penyajian data berbentuk teks naratif diubah menjadi bentuk jenis matriks, grafiks, jaringan dan bagan. Semua dirancang guna menggabungkan informasi yang tersusun dalam bentuk yang padu dan mudah diraih sehingga peneliti dapat mengetahui apa yang terjadi untuk menarik kesimpulan. Kesimpulan data awal berwujud kata-kata dan tingkah laku informan penelitian yang terkait dengan kepemimpinan kepala madrasah dalam meningkatkan kinerja guru, diperoleh melalui observasi dan wawancara seluruh dokumen, selanjutnya reduksi dan disimpulkan (Salim \& Syahrum, 2012).

\section{HASIL DAN PEMBAHASAN}

Kepala madrasah merupakan jabatan karir yang diperoleh seseorang setelah sekian lama menjabat sebagai seorang guru. Seseorang diangkat dan dipercayakan menduduki jabatan kepala madrasah harus memenuhi kriteria-kriteria yang diisyaratkan untuk jabatan tersebut. Jabatan kepala madrasah merupakan orang-orang yang mampu memimpin madrasah dan professional dalam bidang pendidikan.
Mardjiin Syam dalam Yaqin (20II) mendefinisikan kepemimpinan adalah keseluruhan tindakan guna mempengaruhi serta menggiatkan orang, dalam usaha bersama untuk mencapai tujuan, atau dengan definisi yang lebih lengkap dapat dikatakan bahwa kepemimpinan adalah proses pemberian jalan terorganisasi dalam organisasi formal guna mencapai tujuan yang telah ditetapkan. Fungsinya sebagai top manager kepala MTsN I Model Palangka Raya mampu menggerakkan, mempengaruhi serta memberikan dorongan kepada seluruh tenaga kependidikan yang ada dalam institusi pendidikan yang dipimpinnya untuk meningkatkan kinerjanya sebagai pengajar atau pendidik bagi para peserta didik. Sebagai pemimpin "leader" kepala madrasah mampu menggerakkan, seluruh sumber daya yang ada di madrasah untuk bekerja dengan penuh tanggung jawab sesuai dengan tugas dan fungsinya masing-masing.

Berdasarkan temuan penelitian, kepala madrasah di MTsN I Model Palangka Raya memiliki tipe kepemimpinan antara lain telah mendelegasikan tugas, tanggung jawab dan kewenangan kepada bawahan sesuai juknis, selalu menjunjung tinggi prinsip persamaan hak dan persamaan kewajiban semama warga madrasah, berupaya membangun budaya madrasah yang harmonis, toleran, berkeadilan, tidak pilih kasih kepada rekan kerja, transfaran, saling terbuka terhadap semua persoalan dengan musyawarah mufakat agar tidak menimbulkan kecemburuan sosial pada kelompok kerja, selalu menempatkan diri sebagai bagian dari kelompok warga madrasah, dapat menyesuaikan kepentingan ataupun tujuan Madrasah dengan kepentingan bawahan ataupun pribadinya, memberikan kesempatan agar dewan guru lebih berkembang karirnya seperti memberikan kesempatan untuk kuliah S2 dan mengikuti pelatihan-pelatihan, dan memberikan kesempatan untuk memberikan masukan atau saran yang sangat penting dan bersifat membangun untuk terwujudnya visi misi MTsN I Model sehingga dipercaya masyarakat untuk menyekolahkan anak-anaknya. 
Hal tersebut sesuai dengan apa yang dikemukakan oleh Davis dan Thomas mengatakan bahwa sebuah visi memiliki gambaran yang jelas, menawarkan suatu cara yang inovatif untuk memperbaiki, mendorong adanya tindakan-tindakan yang mungkin dilakukan untuk mewujudkan perubahan yang lebih baik. Dalam fungsinya sebagai organisator kepala MTsN I Model Palangka Raya tetap menetapkan organisasi yang efektif melalui perintah secara lansung, karena perintah secara langsung oleh kepala madrasah dianggap efektif, melihat guru-guru sebagai sosok manusia yang menjadi figur bagi peserta didik, metode ini bukan hanya dalam organisasi saja, namun dalam intervensinya sebagai top leader kepada perencanaan dan sekaligus general kontrol kepada bawahan.

Kepala Madrasah sebagai administrator, yaitu melaksanakan fungsi yang diterapkan dalam kegiatankegiatan madrasah yang dipegang antara lain membuat rencana atau program tahunan, menyusun organisasi madrasah, melaksanakan, mengkoordinasi dan mengarahkan, serta melaksanakan pengolahan pengevaluasian. Dalam program tahunan yang dibuat kepala MTsN I Model Palangka Raya meliputi program pengajaran, kepeserta didikan, kepegawaian, keuangan, dan kelengkapan sarana dan prasarana madrasah. Kepala madrasah sebagai supervisor adalah memberikan pujian dan penghargaan kepada para guru yang berprestasi, walaupun sekedar dengan ucapan yang dapat memberi semangat kepada para guru untuk lebih giat dalam melakukan kerja. Untuk dapat menjalankan tugasnya dengan baik, seorang kepala madrasah harus memiliki ketrampilan-ketrampilan tidak saja dibidang administrasi saja, melainkan juga harus memiliki kemampuan memimpin, mengorganisir, mampu memberi motivasi dan dorongan kepada guru, tenaga-tenaga kependidikan, serta para peserta didik untuk belajar lebih giat, sehingga peserta didik dapat memperoleh prestasi dengan baik dan keberhasilan madrasahpun juga akan meningkat dengan cepat.
Kepala madrasah dalam mewujutkan hal tersebut harus memiliki tiga macam ketrampilan. Pertama, keterampilan organisasi. Wujud nyata dari keterampilan ini adalah bagaimana kepala madrasah mampu merumuskan visi dan misi madrasah yang selanjutnya dijabarkan dalam sebuah program pendidikan yang pelaksanaannya disusun sedemikian rupa dalam sebuah rangka organisasi yang tersusun dalam sebuah program pendidikan yang rapi dan sistematis. Kedua ketrampilan manusiawi, yaitu keterampilan untuk bekerjasama, memotivasi dan memimpin. Dan yang ketiga keterampilan teknik, yaitu keterampilan dalam menggunakan pengetahuan, metode, teknik, serta perlengkapan untuk menyelesaikan tugas-tugas tertentu. Kepemimpinan tersebut, kiranya sangat bermanfaat bagi kepala MTsN I Model Palangka Raya untuk melaksanakan tugas-tugasnya sebagai pemimpin yang lebih baik dan lebih berhati-hati agar mampu meningkatkan kinerja guru dan karyawan serta juga meningkatkan prestasi peserta didik secara optimal yang sebagian dari tujuan pendidikan (Djunaidi, 20I7).

Selanjutnya berkaitan dengan kinerja guru MTsN I Model Palangka Raya. Guru merupakan komponen paling menentukan dalam sistem pendidikan secara keseluruhan, yang harus mendapat perhatian sentral, pertama, dan utama. Dalam kaitanya dengan kinerja guru, di MTsN I Model Palangka Raya para guru di sana sudah melakukan kerja yang cukup baik, ini bisa dilihat: I) Dalam proses belajar mengajar guru sudah mengikuti standar pendidikan yang saat ini digunakan yaitu menggunakan kurikulum 20I3. 2) Guru sudah disiplin dalam menjalankan tugasnya sebagai pendidik. 3) Guru juga sudah memberikan motivasi kepada para peserta didik untuk lebih giat belajar. Guru sebagai pendidik dalam menjalankan tugasnya tidak selamanya berjalan dengan lancar, di MTsN I Model Palangka Raya masih ada beberapa kelemahan guru dalam proses pembelajaran antara lain: I) Tidak semua guru menguasai kurikulum yang sekarang ini sedang digunakan. 2) Masih ada beberapa guru yang belum 
disiplin dalam mengajar, dikarnakan masih ada kepentingan-kepentingan pribadi yang tidak bisa ditinggalkan. Dengan demikian, untuk memperoleh predikat kinerja guru dengan baik. Banyak hal yang harus dilakukan dan diperlihatkan guru dalam kegiatan proses pembelajaran, baik pekerjaan yang sifatnya tertulis maupun yang tidak tertulis. Sehingga sebagai guru harus bisa memahami akan tugasnya sebagai pengelola pembelajaran, melaksanakannya, dan berhasil dalam mengajar sehingga tujuan pembelajaran dapat dicapai dengan baik sangat ditentukan oleh konsekuensi dalam memilih strategi mengajar.

Guru di dalam kelas tidak hanya menyampaikan pelajaran saja, tetapi guru juga memberi motivasi kepada para peserta didik. Di MTsN I Model Palangka Raya ini para guru sudah memberikan motivasi kepada para peserta didik, baik itu yang tidak berprestasi maupun yang sudah berprestasi. Tetapi di sini yang lebih diperhatikan lagi kepada para peserta didik yang kurang mampu dalam belajar, para peserta didik yang kurang mampu ini diberi motivasi dan dorongan agar selalu giat belajar. Karena dengan adanya motivasi dari guru para peserta didik akan lebih merasa diperhatikan.

Temuan ketiga adalah kepemimpinan kepala madrasah dalam meningkatkan kinerja guru di MTsN I Model Palangka Raya. Kepemimpinan pendidikan adalah segenap kegiatan dalam usaha mempengaruhi orang lain yang ada dilingkungan pendidikan pada situasi tertentu agar orang lain melalui kerja sama mau bekerja dengan penuh rasa tanggung jawab dan ikhlas demi tercapainya tujuan pendidikan yang telah ditetapkan.

Kepala madrasah merupakan motor penggerak, penentu arah kebijakan madrasah, yang akan menentukan bagaimana tujuan-tujuan madrasah dan pendidikan pada umumnya direalisasikan. Di samping itu kepala madrasah juga berperan penting dalam meningkatkan kinerja guru dan prestasi peserta didik.
Kepemimpinan kepala madrasah dalam kaitannya dengan peningkatan kinerja guru adalah segala upaya yang dilakukan dan hasil yang dapat dicapai oleh kepala madrasah dalam mengimplementasikan manajemen sumber daya pengajar di madrasah dalam mewujudkan tujuan pendidikan. Kepala madrasah mempunyai kedudukan dan fungsi untuk mengarahkan dan mendorong bawahannya agar tugas dan kegiatan di madrasah dapat berjalan dengan baik, efektif dan efisien. Sebagai manajer dialah yang membuat perencanaan, mengatur pelaksanaan, mengendalikan dan mengawasi pelaksanaan tugas-tugas, serta menyusun laporan pelaksanaan kegiatan dari kepala madrasah tersebut. Namun demikian, dilingkungan madrasah juga terdapat tuntutan agar kepala madrasah juga mampu untuk berkomunikasi serta mampu memobilisasi partisipasi masyarakat.

Kepala MTsN I Model Palangka Raya juga melakukan hal yang sama, beliau menjadi motor penggerak dalam meningkatkan kinerja guru. Dalam melaksanakan tugas dan fungsinya, kepala madrasah memiliki gaya kepemimpinan masing-masing yang sangat mempengaruhi kinerja para tenaga kependidikan di lingkungan kerjanya masing-masing. Kegagalan dan keberhasilan madrasah banyak ditentukan oleh kepala madrasah, karena kepala madrasah merupakan pengendali dan penentu arah yang hendak ditempuh oleh madrasah menuju tujuannya.

Hal tersebut sejalan dengan temuan Hackman dan Oldman yang dirujuk Sergiovanni (2014) menyatakan bahwa guru-guru yang diberi petunjuk tentang teknik pelaksanaan pekerjaan secara jelas dan wajar akan terdorong untuk meningkatkan kualitas dan kemampuan kerjanya. Dengan demikian, keberhasilan sekolah dalam mencapai tujuan pendidikan tidak saja dipengaruhi oleh kinerja guru, namun ikut berperan pula faktor kepemimpinan kepala sekolah dalam manajemen serta dalam menciptakan suasana pembelajaran yang kondusif. 
Blumberg \& Greenfield (1980) dalam penelitiannya mengungkapkan bahwa salah satu karakteristik kepala sekolah yang efektif adalah kepala sekolah yang mempunyai harapan tinggi terhadap prestasi siswa dan unjuk kerja guru. Agar dapat merealisasikan harapan tersebut kepala madrasah harus mampu mengoptomalkan sumberdaya di sekolah dengan menjalankan kompetensi manajerial.

Upaya atau kiat-kiat lain yang dilakukan kepala $\mathrm{MTsN}$ I Model Palangka Raya dalam meningkatkan kerja guru antara lain dengan: I) Memberikan dorongan timbulnya kemauan yang kuat kepada guru agar percaya diri dan semangat dalam menjalankan tugasnya. 2) Memberi bimbingan, pengarahan dan dorongan untuk berdiri di depan demi kemajuan dan memberikan inspirasi madrasah dalam mencapai tujuan. 3) Membujuk dan memberi keyakinan kepada guru dalam mengerjakan tugasnya. 4) Menghindari sikap dan perbuatan yang bersifat memaksa atau bertindak keras dalam memberikan tugas kepada para guru.

Kepala MTsN I Model Palangka Raya juga memberikan pelatihan bagi para guru dengan cara mengikut sertakan guru dalam berbagai pelatihan sesuai dengan bidangnya masing-masing. Selain itu salah satu tugas kepala madrasah dalam meningkatkan kinerja guru adalah sebagai supervisor. Kinerja kepala madrasah sebagai supervisor menuntut kemampuan kepala madrasah dalam melakukan pengawasan dan pengendalian untuk meningkatkat kualitas tenaga kependidikan. Kegiatan supervisor kepala MTsN I Model Palangka Raya kepada guru dilakukan secara langsung maupun tidak langsung. Program ini selalu dijalankan oleh kepala madrasah mengingat pentingnya peningkatan profesionalisme tenaga mengajar dan pengembangan akademik. Untuk mengetahui kinerja guru apakah sudah berjalan dengan baik atau tidak, kepala MTsN I Model Palangka Raya melakukan evaluasi setiap satu semester sekali, dan pada akhir tahun juga ada evaluasi lagi serta penyusunan program kerja. Selain itu juga adanya pembinaan kepada para guru ini dilakukan setiap satu bulan sekali.

Kepala madrasah merupakan komponen yang sangat penting dan bertanggung jawab terhadap pelaksanaan pendidikan, dalam kaitannya dengan peningkatan kerja guru, kepala madrasah bertanggung jawab mengarahkan apa yang baik untuk anggotanya sedangkan beliau sendiri harus berbuat baik. Kepala madrasah harus menjadi contoh, sabar dan penuh pengertian.

\section{KESIMPULAN}

Kepala madrasah di MTsN I Model Palangka Raya memiliki tipe kepemimpinan demokratis dan sangat berperan dalam menjalankan kepemimpinannya sebagai edukator, manager, administrator, supervisor, leader, inivator dan motivator dalam meningkatkkan kinerja dalam perencanaan, pelaksanaan dan evaluasi pembelajaran di kelas.

Kinerja guru di MTsN I Model ini, sudah melakukan analisis minggu efektif, prota, prosem, tersedianya silabus media, daftar nilai, dan daftar hadir peserta didik. Kinerja guru mata pelajaran dalam perencanaan pembelajaran sudah dalam kategori baik sekali. Guru sudah disiplin dalam menjalankan tugasnya sebagai Pendidik. Dalam pelaksanaannya untuk meningkatkan kinerja guru, kepala madrasah sudah mengikutkan para guru setiap ada pelatihan-pelatihan sesuai dengan bidang studi. Disamping itu kepala madrasah juga memberikan penghargaan kepada guru, walaupun tidak berupa materi akan tetapi berupa dukungan mental dan pujian untuk terus mengembangkan potensi yang dimilikinya.

\section{REFERENSI}

Blumberg, A. \& Greenfield, W. 1986. The Effective Principal: Perspectives on School Leadership. Boston: Allyn and Bacon.

Bogdan, R.C. \& Biklen, S.K. 2007. Qualitative Research For Education: An Introduction to Theories and Methods. Boston: Allyn and Bacon. 
Danim, S. 2002. Inovasi Pendidikan: Dalam Upaya Meningkatkan Profesionalisme Tenaga Kependidikan. Bandung: Pustaka Setia.

Danim, S. 2006. Visi Baru Manajemen Madrasah: Dari Unit Birokrasi ke Lembaga Akademik. Jakarta: Bumi Aksara.

Danim, S. 2006. Agenda Pembaruan Sistem Pendidikan. Yogyakarta: Pustaka Pelajar.

Davis, G.A. \& Thomas, M.A. 1989. Effective School and Effective Teachers. Boston: Allyn and Bacon.

Djunaidi. 2017. Kepemimpinan Kepala Sekolah dalam Meningkatkan Kinerja Guru. Jurnal Tarbiyatuna. 2(1):89-I I8.

Dunkin, M.J. 200I. Assesing Teachers' Effectiveness. Issues Educational Research. 7(1):37-5I.

Fullan, M.G. 2007. The New Meaning of Educational change. Fifth Edition. New York: Teacher College Press.

Megginson, J.C., Mosley, D.C., \& Pietri, P.H. 1992. Management: Concepts and Applications. Fourth Edition. New York: Harper Collins Publisher.

Moedjiarto. 2002. Madrasah Unggul: Metodologi untuk Meningkatkan Mutu Pendidikan. Surabaya: Duta Graha.

Nawawi, H. \& Hadari, M. 2014. Kepemimpinan yang Efektif. Yogyakarta: Gajah Mada University, Press.

Ngafifi, M. 2012. Kemajuan Teknologi dan Pola Hidup Manusia dalam Perspektif Sosial Budaya. Jurnal Pembangunan Pendidikan: Fondasi dan Aplikasi. 2(I):33-47.

Rivai, V. \& Mulyadi, D. 2017. Kepemimpinan dan Perilaku Organisasi. Jakarta: Raja Grafindo Persada.

Sagala, S. 2018. Administrasi Pendidikan Kontemporer. Bandung: Alfabeta.

Salim \& Syahrum. 2012. Metodologi Penelitian Kualitatif. Bandung: Cipta Pustaka.

Sergiovanni, T.J. 20I4. The Principalship: A Reflective Practice Perspective. Seventh Edition. Boston: Allyn and Bacon.

Suryadi, A. \& Tilaar, H.A.R. 1994. Analisis Kebijakan Pendidikan: Suatu Pengantar. Bandung: Remaja Rosdakarya.
Suwarni. 2009. Pengaruh Budaya Organisasi, Keterampilan Manajerial Kepala Sekolah dan Pelaksanaan Fungsi Pengawasan terhadap Kinerja Guru-guru Ekonomi SLTA di Kota dan Kabupaten Blitar. Jurnal Ekonomi Bisnis. |4(2): $|7|-\mid 78$.

Suyanto. 2014. Peran dan Strategi Pimpinan Lembaga Pendidikan Islam dalam Mengatasi Problem Kepemimpinan. Quality: Journal of Empirical Research in Islamic Education. 2(2):222-234.

Undang-Undang Pemerintah Republik Indonesia No. 20 Tahun 2003 tentang Sistem Pendidikan Nasional.

Wibowo, A. 2012. Pendidikan Karakter, Strategi Membangun Karakter Bangsa Berperadaban. Yogyakarta: Pustaka Pelajar.

Yaqin, H. 20ll. Kapita Selekta Administrasi dan Manajemen Pendidikan. Banjarmasin: Antasari Press.

Yin, R.K. 2002. Studi Kasus Desain dan Metode. Terjemahan oleh M. Djuazi Mudzakir. Jakarta: Raja Grafindo Persada. 